\title{
THE EFFECTIVENESS OF COLLABORATIVE LEADERSHIP ON IMPROVING INTERPROFESSIONAL COLLABORATION PRACTICE IN THE COMPREHENSIVE EMERGENCY OBSTETRIC AND NEONATAL SERVICES
}

\author{
Sulistyaningsih'1), Y. Warella²), Sutopo Patria Jati3), Meidiana Dwidiyanti3) \\ 1)Faculty of Health Sciences, Universitas 'Aisyiyah Yogyakarta \\ 2)Faculty of Social Science and Political Science, Universitas Diponegoro \\ 3) Faculty of Public Health, Universitas Diponegoro \\ 4)Department of Nursing, Faculty of Medicine, Universitas Diponegoro
}

\begin{abstract}
Background: Maternal and infant mortality rates remain high in most developing countries including Indonesia. An approach so called as the interprofessional collaboration (IPC) has been considered to have its potential to improve the emergency obstetric and neonatal care. Little is known about the effectiveness of leadership in enhancing IPC. This study aimed to determine the effectiveness of leadership on improving the IPC in the comprehensive emergency obstetric and neonatal services.

Subjects and Method: This was a qualitative study using an embedded case study approach. This study was conducted at PKU Muhammadiyah Gamping Hospital, Yogyakarta, as a type C teaching hospital. The data were collected by observation, in-depth interview, and document review.

Results: This study found three themes: (1) collaborative leadership; (2) leadership issues; and (3) stakeholder input. The inter-professional collaboration included doctors, consultant doctors, supervisor, shift coordinator, and nurses in charge of nursing care. The interprofessional collaboration had been implemented. The principle of leadership had supported the interprofessional collaboration. The IPC team had understood and applied the principles of leadership that support the IPC. The leadership attributes on demand for the IPC included visionary, participatory, and coaching. The leadership issues included the difference in advice between doctors. The theme for nurses was improving the quality of interprofesional collaboration.

Conclusion: The leadership attributes to improve the interprofessional collaboration include visionary, participatory, and coaching for the comprehensive emergency obstetric and neonatal services.
\end{abstract}

Keywords: interprofessional collaboration, leadership

\section{Correspondence:}

Sulistyaningsih. Faculty of Health Sciences, Universitas 'Aisyiyah Yogyakarta. Jl. Siliwangi (Lingkar Barat) No. 63 Pundung, Nogotirto, Gamping, Sleman, DIY, Indonesia. Email: sulistyaningsih@unisayogya.ac.id. Mobile: +6281328067154

The $7^{\text {th }}$ International Conference on Public Health Solo, Indonesia, November 18-19, 2020 | 334 https://doi.org/10.26911/the7thicph.04.19 